\title{
Histiocitoma fibroso Benigno lingual. Un hallazgo infrecuente
}

\section{Benign lingual fibrous histiocytoma. An uncommon finding}

\section{Sr. Director,}

En ocasiones, la práctica clínica nos sorprende con hallazgos inesperados. La lengua es un órgano accesible a la exploración clínica directa, razón por la que su patología suele ser diagnosticada precozmente (exceptuamos la semiótica de localización en base lingual); ello permite realizar la exéresis y el posterior estudio histológico de lesiones que terminan siendo encasilladas, en la mayoría de las ocasiones, dentro de un relativamente limitado grupo de patologías, principalmente epiteliales. El hallazgo en esta localización de lesiones de tejidos blandos puede ser considerado infrecuente. Si se trata de lesiones fibrohistiocitarias del tipo histiocitoma fibroso benigno son escasos los casos referidos en la literatura. ${ }^{1-2}$

Queremos presentar con esta carta el caso de un paciente varón de 50 años que acudió a consulta debido a la presencia de una lesión excrecente en punta lingual. El juicio clínico fue de papiloma de lengua. Se procedió a la exéresis quirúrgica y se remitió la pieza para estudio anatomopatológico.

Se trataba de una lesión semiesférica de consistencia firme y tonalidad pardusca que medía $0,4 \mathrm{~cm}$. de dimensión máxima. El estudio histológico de la muestra remitida permitió identificar una lesión fusocelular con patrón estoriforme focal en cuyo seno se observaban tractos fibrosos ramificados en relación a grupos de células fusiformes sin atipia nuclear que adquirían una morfología epitelioide en superficie, donde adoptaban características histiocitarias, confirmadas con el marcador inmunohistoquímico CD68. El marcador CD34 puso de manifiesto el patrón vascular lesional siendo negativo en la población celular proliferante. Ésta, alcanzaba con márgenes infiltrativos la interfase con el músculo estriado sin penetrarlo. El epitelio, ulcerado, exhibía intensa acantosis, exocitosis y paraqueratosis. Con tales datos se emitió el diagnóstico de histiocitoma fibroso benigno (Figs. 1 y 2 ).

Como previamente hemos comentado, se trata de una lesión frecuente a nivel cutáneo pero sumamente infrecuente en localización lingual por lo que la experiencia en su manejo en esta última localización es escasa o nula. Si realizamos analogías con su comportamiento cutáneo, es predecible un comportamiento recidivante si bien éste puede ser minimizado con una adecuada exéresis quirúrgica. En nuestro caso se alcanzó el plano muscular permaneciendo los límites lesionales respetados. La lesión no ha vuelto a recurrir si bien el periodo de seguimiento es corto (escasos meses). Los casos referidos en la literatura a los que hemos tenido acceso han sido enjuiciados clínicamente como granulomas piógenos de lento y progresivo crecimiento; la exéresis quirúrgica ha sido el tratamiento aplicado en todos los casos. En
Dear Editor,

On occasions, we encounter unexpected findings in clinical practice. The tongue is an organ accessible to direct clinical examination, which is why lingual pathology usually is diagnosed early (except for symptoms of the lingual base). This makes it possible to perform exeresis and a histologic study of the lesions, which in most cases end up being classified into a relatively small group of pathologies, mainly epithelial. The finding of soft tissue lesions in this location can be considered infrequent. If fibrohistiocytic lesions of the benign fibrous histiocytoma type are involved, few cases have been reported in the literature $(1,2)$.

We wish to present in this letter the case of a 50 -yearold man who was seen in the clinic for an excrescent lesion on the tip of the tongue. The clinical opinion was lingual papilloma. Surgical exeresis was performed and the piece was sent for histopathologic study.

The lesion was semi-spherical and of firm consistency with a brownish tone. It measured $0.4 \mathrm{~cm}$ in its maximum diameter. Histologic study of the specimen allowed the identification of spindle-cell lesions with a focal storiform pattern in which ramified fibrous tracts were observed in relation to groups of spindle cells without nuclear atypia that acquired an epithelioid surface morphology, where they took on histiocytic characteristics that were confirmed by the immunohistochemical marker CD68. The CD34 marker showed the vascular pattern of the lesion, being negative in the proliferating cell population. It reached the interface with striate muscle with infiltrative margins without penetrating it. The ulcerated epithelium exhibited intense acanthocytosis, exocytosis, and parakeratosis. With this information the diagnosis of benign fibrous histiocytoma was made (Figs. 1 and 2).

As previously commented, it is a frequent skin lesion but it is extremely uncommon in the tongue and there is little or no experience with its management in this location. In view of its cutaneous behavior, recurrence can be expected, although it can be minimized with proper surgical exeresis. In our case, the muscular plane was reached, but the margins of the lesion were intact. The lesion has not recurred, although the follow-up period is short (a few months). The cases cited in the literature to which we have had access have been judged clinically as pyogenous granulomas of slow 
cuanto a la histología, dos casos fueron denominados como histiocitoma epitelioide ${ }^{3,4} \mathrm{y}$ uno de ellos como histiocitoma fibroso atípico. ${ }^{5}$ Casos de histiocitoma fibroso maligno de localización lingual son más frecuentes en la literatura, asociados o no a radioterapia regional:6 Sin embargo hay que señalar que se trata de una neoplasia maligna desdiferenciada en cuyo grupo se han englobado tradicionalmente neoplasias heterogéneas sin signos de diferenciación clara.

Analizando nuestro caso, observamos un crecimiento lesional bidireccional, hacia la profundidad, sin alcanzar el músculo estriado, y hacia el plano epitelial, obviando la interfase epitelio-lámina propia, característica que podríamos considerar como peculiar de las lesiones de localización mucosa frente a la más frecuente ubicación cutánea. El origen de la población proliferante no está del todo claro si bien no podemos descartar que se trate de lesiones reactivas a trauma previo. Nuestro caso es el único referido a la punta lingual.

\section{Bibliografía}

1. Thompson S, Shear M. Fibrous histiocytomas of the oral and maxillofacial regions. J Oral Pathol 1984;13:282.

2. Regezi J, Zarbo R, Tomich C. Immunoprofile of benign and malignant fibrohistiocytic tumors. I Oral Pathol 1987; 16:260.

3. Rawal YB, Kalmar JR, Shumway B, Mallory SR. Presentation of an epithelioid cell histiocytoma on the ventral tongue. Oral Surg Oral Med Oral Pathol Oral Radiol Endod 2005;100:75-83.

4. Takimoto T, Ishikawa S, Umeda R. Fibrous histiocytoma of the tongue base. Auris Nasus Larynx 1990;16:233-36.

5. Velez Torres R, Owen LG, Hodge SI, McMurray GT, Roe E. Atypical fibrous histiocytoma of the tongue. A case report. Int / Dermatol 1986;25 :656-57.

6. Lin SK, How SW, Wang JT, Liu BY, Chang CP. Oral post-radiation malignant fibrous histiocytoma. A clinicopathological study. Oral Pathol Med 1994;23: 324-29.

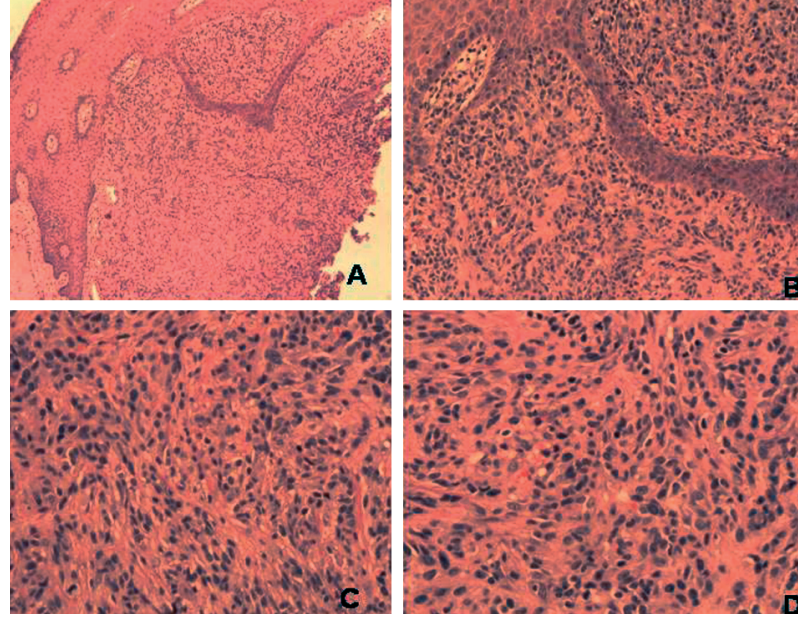

Figura 1. Benign fibrous histiocytoma of the tip of the tongue. A: Panoramic image. HE, 40x. B. Histologic detail of the spindle-cell component. HE, 100x. C and D: Storiform pattern. Details. $\mathrm{HE}, 200 \mathrm{x}$.

Figure 1. Benign fibrous histiocytoma of the tip of the tongue. A: Panoramic image. HE, 40x. B. Histologic detail of the spindle-cell component. HE, 100x. C and D: Storiform pattern. Details. HE, 200x.
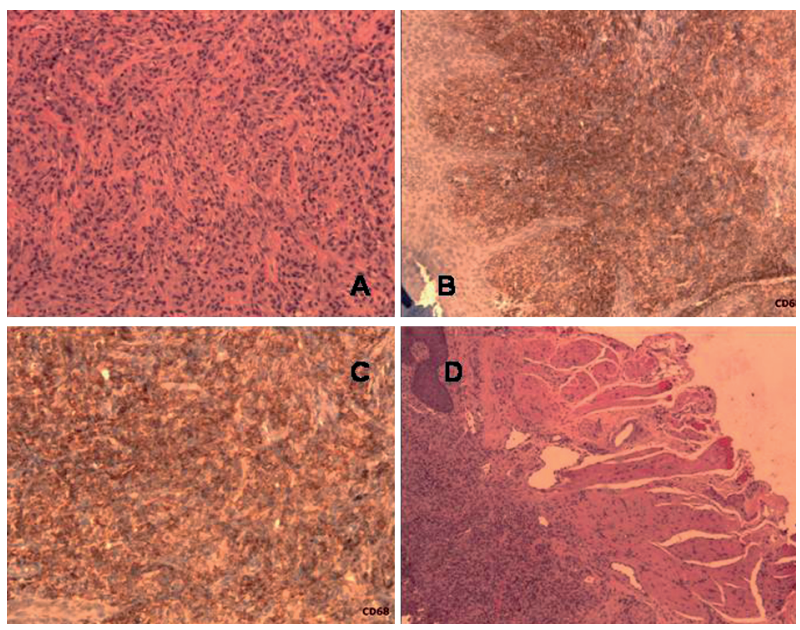

Figura 2. Benign fibrous histiocytoma of the tip of the tongue. A: Histology. HE, 200x. B: Immunohistochemical positivity for CD68. Panoramic image. 40x. C: Immunohistochemical positivity for CD68. Detail. 100x. D: Lesion-striate muscle interface. HE, 100x.

Figure 2. Benign fibrous histiocytoma of the tip of the tongue. A: Histology. HE, 200x. B: Immunohistochemical positivity for CD68. Panoramic image. 40x. C: Immunohistochemical positivity for CD68. Detail. 100x. D: Lesion-striate muscle interface. HE, 100x. and progressive growth. Surgical exeresis was the treatment used in every case. As far as the histology, two cases were identified as epithelioid histiocytoma $(3,4)$ and one as atypical fibrous histiocytoma (5). Cases of malignant fibrous histiocytoma of lingual location are more common in the literature, whether or not associated with regional radiotherapy (6). However, it should be noted that it is an undifferentiated malignant neoplasm in a group in which heterogeneous neoplasms have been included traditionally without clear signs of differentiation.

Analyzing our case, we observed bidirectional growth of the lesion in depth, without reaching the striate muscle, and toward the epithelial plane. The epitheliumlamina propria interface is not involved, a characteristic that can be considered typical of the mucosal lesions as opposed to more common skin locations. The origin of the proliferating population is not absolutely clear, although we cannot rule out the possibility of lesions reactive to previous trauma. Our case is the only one of the tip of the tongue.

\section{Francisco Javier Torres Gómez}

Unidad de Anatomía Patológica

Hospital de Alta Resolución de Utrera

Eusebio Torres Carranza

Servicio de Cirugía Oral y Maxilofacial

Hospital Universitario Virgen del Rocío

Sandra Moreno Corral (TEAP)

Unidad de Anatomía Patológica

Hospital de Alta Resolución de Utrera 